February 2001 - NREL/TP-620-29408

\title{
Customer Aggregation: An Opportunity for Green Power?
}

Edward Holt

Ed Holt \& Associates, Inc.

Lori Bird

National Renewable Energy Laboratory

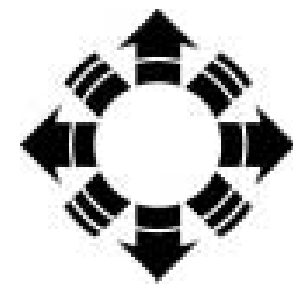

\section{NPEI}

National Renewable Energy Laboratory

1617 Cole Boulevard

Golden, Colorado 80401-3393

NREL is a U.S. Department of Energy Laboratory

Operated by Midwest Research Institute $\bullet$ Battelle $\bullet$ Bechtel

Contract No. DE-AC36-99-G010337 
February 2001 • NREL/TP-620-29408

\section{Customer Aggregation: An Opportunity for Green Power?}

Edward Holt

Ed Holt \& Associates, Inc.

Lori Bird

National Renewable Energy Laboratory

Prepared under Task No. AS65.3010
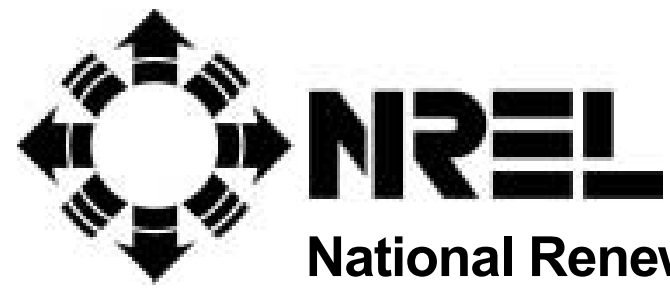

National Renewable Energy Laboratory

1617 Cole Boulevard

Golden, Colorado 80401-3393

NREL is a U.S. Department of Energy Laboratory

Operated by Midwest Research Institute $\bullet$ Battelle $\bullet$ Bechtel

Contract No. DE-AC36-99-G010337 


\section{NOTICE}

This report was prepared as an account of work sponsored by an agency of the United States government. Neither the United States government nor any agency thereof, nor any of their employees, makes any warranty, express or implied, or assumes any legal liability or responsibility for the accuracy, completeness, or usefulness of any information, apparatus, product, or process disclosed, or represents that its use would not infringe privately owned rights. Reference herein to any specific commercial product, process, or service by trade name, trademark, manufacturer, or otherwise does not necessarily constitute or imply its endorsement, recommendation, or favoring by the United States government or any agency thereof. The views and opinions of authors expressed herein do not necessarily state or reflect those of the United States government or any agency thereof.

Available electronically at http://www.doe.gov/bridge

Available for a processing fee to U.S. Department of Energy

and its contractors, in paper, from:

U.S. Department of Energy

Office of Scientific and Technical Information

P.O. Box 62

Oak Ridge, TN 37831-0062

phone: 865.576.8401

fax: 865.576.5728

email: reports@adonis.osti.gov

Available for sale to the public, in paper, from:

U.S. Department of Commerce

National Technical Information Service

5285 Port Royal Road

Springfield, VA 22161

phone: 800.553.6847

fax: 703.605.6900

email: orders@ntis.fedworld.gov

online ordering: http://www.ntis.gov/ordering.htm

Printed on paper containing at least $50 \%$ wastepaper, including $20 \%$ postconsumer waste 


\section{Table of Contents}

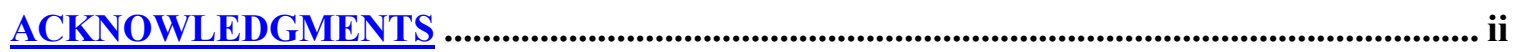

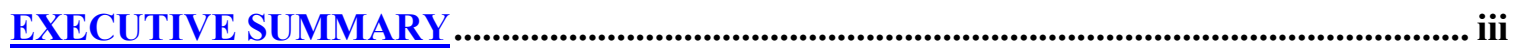

INTRODUCTION

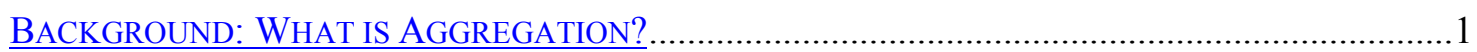

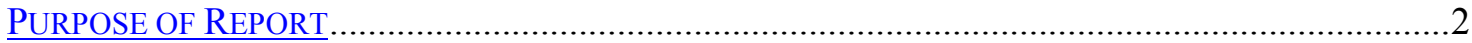

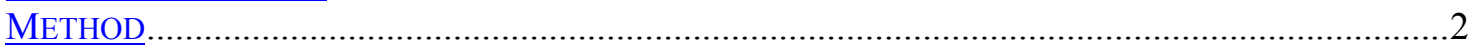

TYPES OF AGGREGATION......................................................................................................

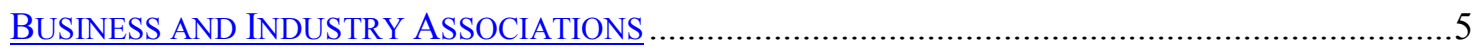

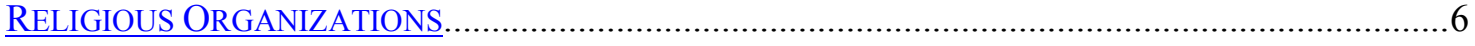

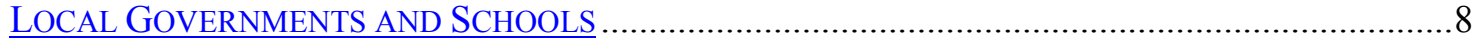

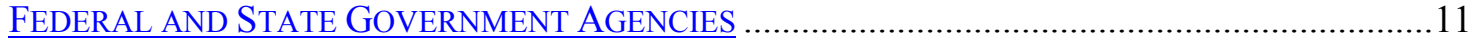

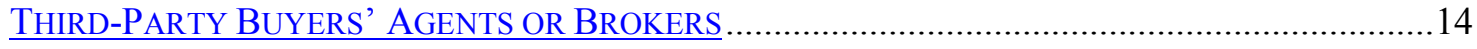

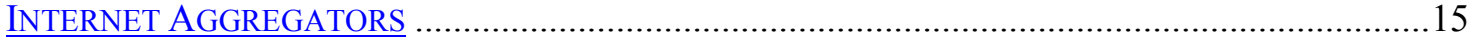

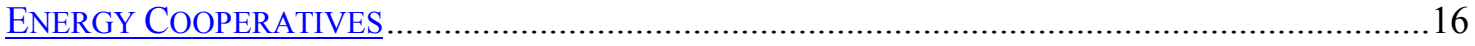

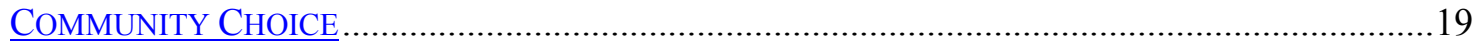

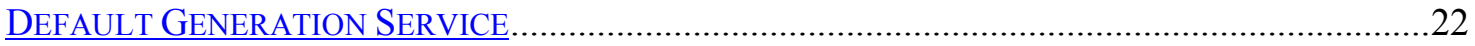

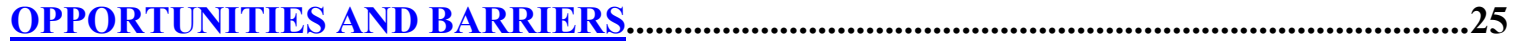

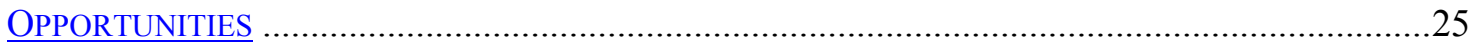

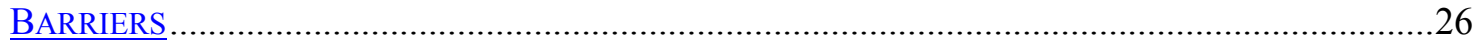

RECOMMENDATIONS AND CONCLUSIONS …..................................................................29

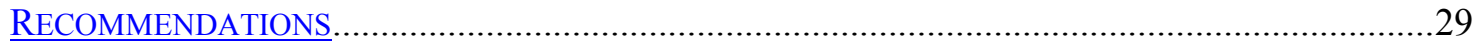

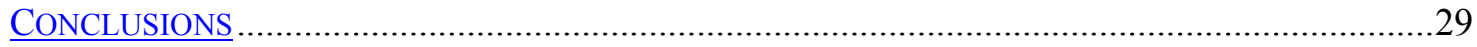

BIBLIOGRAPHY 


\section{Acknowledgments}

This work was funded by the Office of Power Technologies of the U.S. Department of Energy (DOE). The authors wish to thank Tina Kaarsberg and Joe Galdo of DOE for their support of this project. They also wish to thank the following reviewers for their thoughtful comments and suggestions: Adam Serchuk and David Lineweber of Primen; Ryan Wiser of Lawrence Berkeley Laboratory; Rudd Mayer of the Land and Water Fund of the Rockies; Erika Morgan of Energetic Management Associates; and Blair Swezey, Kevin Porter, and Larry Goldstein of the National Renewable Energy Laboratory (NREL). Lastly, the authors wish to thank Stuart Smoller and Rene Howard of NREL for their editorial review. 


\section{Executive Summary}

In several state markets, small consumers have not yet obtained the projected benefits of electricity restructuring. There are a variety of reasons for this. One is that retail suppliers find it too costly to advertise to, inform, acquire, and service small consumers. Thus, the aggregation of consumers (small and large) into buying groups has emerged as an important strategy for reducing transaction costs and obtaining cost savings or a different combination of services. Examples of groups that have aggregated electricity loads to take advantage of their combined purchasing power in newly competitive markets include affinity groups such as chambers of commerce, associations of retailers or building operators, and end users such as school districts with multiple facilities and government agencies. These and other groups have adopted aggregation as a purchasing strategy, because other factors being equal, larger groups are more attractive to a supplier and have more purchasing leverage with suppliers competing for their business.

Green power marketers suffer from some of the same problems faced by other marketers-it is expensive to market to individual customers; education is important, but costly; and in many cases, demand must be sufficient to make it worthwhile to obtain supplies. Any efforts to reduce transaction and marketing costs, such as aggregation, may broaden the customer base interested in green power products, particularly because these products are typically offered at a premium. To date, about a dozen existing aggregation groups and a few newly formed aggregators have attempted to procure green power for their members or customers.

We undertook research into the experience of aggregation groups to determine whether customer aggregation offers an opportunity to bring green power choices to more customers. The objectives of this report, therefore, are to (1) identify the different types of aggregation that are occurring today, (2) learn whether aggregation offers an opportunity to advance sales of green power, and (3) share these concepts and approaches with potential aggregators and green power advocates.

Based on this review of aggregation activity in electricity markets, aggregation does appear to hold potential for increasing demand for green power. Some key findings of this research follow.

- Aggregation groups play different roles - they can be buying agents for their members, they can be providers or resellers of green power, or they can simply endorse a particular product(s). Regardless of the method, the group's members can be given a green power choice. However, the ability to negotiate cost savings may be influenced by the group's role. A group acting as a provider or reseller of green power may be more effective in offering a discount to its members than one merely endorsing a green power provider. Serving as a provider or reseller, however, requires more sophistication and knowledge of the industry, and some groups may shy away from the risk.

- Aggregation for green power faces several barriers - the extra cost of green power, the need for greater education and information about green power benefits, market rules that dampen competitive markets, the lack of human capital for organizing group-buying and green power options, and the scarcity of renewable resources for green power products in some markets. The one barrier that is somewhat unique to aggregation efforts is the scarcity of human capital for organizing group-buying and green power options.

- Today, groups are more likely to offer or purchase green power if the group's mission is related to environmental protection. Those aggregators that have already shown some success - energy cooperatives; local, state, and federal governments; and religious organizations with an environmental 
focus - are likely to have continued success as markets become more fluid and green power supplies grow.

- Some groups have targeted an existing member base; others, such as energy cooperatives, have been created to aggregate electricity purchases. So far, most aggregation efforts have targeted existing groups, particularly those with some experience in bulk purchasing. Forming an aggregation group comes with its own set of challenges, including the need for technical and financial infrastructure, energy supply, billing capabilities, and call centers. However, establishing new groups seems feasible, and at least for energy cooperatives, the necessary technical support services exist.

- As new markets open to competition and as markets already open to competition become more active, a number of groups hold promise as green power aggregators. Community choice - the term we have chosen for the aggregation by a municipality of its residents and businesses - may hold promise, although it has had limited success to date. Based on early experience, it may require a lengthy political process and it is more likely to be effective if residents and businesses are automatically included in the aggregation, with the opportunity to opt out. In addition, Internet buying groups will probably continue to grow rapidly; however, whether they will provide a significant market for green power remains to be seen. 


\section{Introduction}

In newly restructured electricity markets, green power has gained a niche. In states that have seen the most customer switching, namely California and Pennsylvania, nearly $2 \%$ of all residential customers are being served by a green power product (Wiser, Bolinger, and Holt 2000; Swezey and Bird 2000). Other states such as Rhode Island, Massachusetts, Maine, Connecticut, New Jersey, and New York have either offered retail choice for too short a time, or have few offers available and hence too little switching activity to register much of an impact.

If customers do switch, however, a significant share appears to choose green power. Some of these are saving money from high standard-offer prices or from state subsidies to renewable energy, but others pay a premium for a green power product. Although early experience in the marketplace has illuminated some shortcomings, green power definitely shows promise. But how do we increase demand for green power in those states where it already exists, and lower the barriers to green power in states that are just now opening their markets?

There are many possible answers to how to make the market grow. One approach that has figured in all open markets, although not necessarily for green power, is aggregation of customer loads. Dozens, if not hundreds, of buyers' groups have expanded from an existing affinity group (such as a trade organization) to include electricity purchases, or have formed with the primary purpose of buying electricity.

\section{Background: What is Aggregation?}

Aggregation is the combination of individual electricity buyers (and their loads) into a large pool. Other factors being equal, suppliers prefer dealing with larger groups, which have more purchasing leverage with suppliers competing for their business. This purchasing power can be used to obtain cost savings, a different combination of services, or more favorable service terms. Aggregation also reduces transaction costs for the members of the buyers' group and for the suppliers.

From the electricity supplier's perspective, aggregation lowers its marketing and customer acquisition costs, and may improve its load factor. Before restructuring of the electric industry, utilities, as monopolies, served the ultimate aggregation of all customers in their service territories. After restructuring most distribution utilities will continue to serve large blocks of customers who do not actively choose an alternate supplier.

Aggregation can benefit both large and small customers. Large customers have been the quickest to benefit from aggregate purchasing of electricity. Because residential and other small customers are more expensive to serve, and less cost-effective to market to, they may find aggregation more critical to their ability to obtain a desirable alternative service option. Some would say that aggregation is essential to serving residential customers (Environmental Futures, Inc., Tellus Institute, and EUA Citizens Conservation 1998).

Aggregators - those who organize the buyers' groups - may be either buying agents or providers. The major difference between these two approaches is whether the aggregator will purchase power for resale to the aggregation pool (Marshall and Colton 1998; Rader and Hempling 2000). As the phrase is used in this report, buying agents do not purchase and resell power to the members of the group. Instead, they arrange for the purchase directly by the members by selecting a supplier and negotiating terms. Often these agents become involved in the organization of the buyers' pool. Others simply identify and endorse a preferred product for their members. As providers, the aggregator will take title to the power and resell 
it at retail to the members of the group. They may also provide other services desired by the group, such as other forms of energy or energy efficiency.

\section{Purpose of Report}

Why is aggregation of interest to green power markets? If aggregation is a potential way to attract supplier interest and obtain terms of service attractive to the buying pool, it could also be used to bring green power choices to more customers or to lower the cost of green power options.

The objectives of this report, therefore, are to:

- Identify the different types of aggregation that are happening today.

- Learn whether aggregation offers an opportunity to advance sales of green power.

- Share these concepts and approaches with potential aggregators and green power advocates.

\section{Method}

This report uses the case study method to reveal the potential of aggregation to increase the demand for green power. Buying groups with an explicit interest in green power were included; however, we also included examples of buying groups that do not offer or desire to offer green power. First, we surveyed literature and press reports of aggregation, in some cases going back to 1997. In this review, we identified more than 100 electricity load aggregation groups. Some of these had fairly complete descriptions; others were identified only by name. Next, we organized them into categories by type of sponsorship, type of aggregator, or type of members, and identified contact persons or other sources of information about the groups. Third, we selected a representative set from each category for further research. This research relied on Web sites, media reports, and telephone interviews. Finally, we summarized those cases that offered lessons learned and varied approaches, while maintaining representation from each category of aggregation activity. 


\section{Types of Aggregation}

There are a number of ways to think about electricity aggregation activities. Existing groups or associations often aggregate members to enhance their purchasing power or to provide an additional service to their members-something that might be termed association-based aggregation. Examples of this are business and industry associations, associations of municipal governments, and in some cases religious organizations (the churches themselves, if not their parishioners) who aggregate their members. Another type of aggregation, often thought of as traditional aggregation, is conducted by third-party buying agents who organize buying pools. These buying agents are generally private companies, including those that rely on the Internet to find buyers for the pool.

In this report, we have chosen to define aggregation broadly and inclusively, because there are innovative ways of combining demand for power that are worth highlighting and that may stimulate emulation. For example, we also include what might be called self-aggregation, when groups such as local governments, school districts, and federal and state governments combine multiple accounts for greater purchasing leverage. Private companies with multiple facilities, such as Toyota, Kinko's, or Patagonia, often aggregate their own loads as well, although we have not specifically included any examples of this.

Another type of aggregation — which might be called affinity-based aggregation — relies on group endorsement of a particular supplier or product. Under this framework, group members are encouraged to buy an endorsed product, and sometimes the group earns a fee from the supplier for each member of the group that signs up. This has been the experience of some religious groups that encourage their members to sign up with a particular supplier, as well as some environmentally oriented organizations. They may have little direct effect on the price of electricity, and may be offered only off-the-shelf products. This could also be thought of simply as innovative marketing, and it may stretch the definition of aggregation.

Aggregators that resell electricity as providers are somewhat difficult to distinguish from standard retail marketers or suppliers. However, we make a distinction between member-based organizations that sell power, such as energy cooperatives, and regular retail suppliers. The rationale for this is that energy cooperatives are member-based like aggregation groups, and are democratically controlled with a share of profits returned to members. In addition, cooperatives evidence a social and environmental mission that supports a particular interest in green power. Traditional rural electric cooperatives are not addressed in this report, however, because they are not yet active in competitive markets.

Finally, we discuss aggregation that is determined by state regulation, such as in the case of default service (often called the standard offer), or by local policy, such as when communities vote to aggregate the electric loads of their residents and businesses. We call this automatic aggregation. It is arguable whether automatic aggregation should be included because it is not voluntary, but we did so because it offers another market opportunity for green power. We did limit its consideration to situations where customers are switched to an alternative provider, as opposed to being served by their traditional utility.

The discussion above is intended to help explain why certain examples are included in this study of aggregation and green power. However, we have chosen to present the examples in a different way, by the type of customer or organization. We feel that these groups may be easier to recognize and understand. In addition, this method of presentation may help in identifying other groups that might be receptive to aggregation.

- Business and Industry Associations - Established industry associations may wish to serve as aggregators to offer their members savings on electricity costs, provide their members with differentiated power products, or expand their membership. They may be either buyers' agents or 
energy providers. Typically, these groups are involved in association-based or affinity-based aggregation.

- Religious Organizations - Faith-based groups may wish to serve as aggregators to offer their members savings on electricity costs or provide their members with environmentally friendly power options. Aggregation of the electric loads of religious facilities falls into the category of associationbased aggregation; however, signing up individual households belonging to these religious organizations is more akin to affinity-based aggregation.

- Local Governments and Schools - City governments and school districts may be interested in aggregating their electricity purchases to obtain a better rate, reduce transaction costs, or purchase power generated from sustainable energy sources. School systems may be interested in purchasing power from renewable resources to educate students about renewable energy technologies and the benefits of clean power. Typically, these groups are aggregating their own loads and, thus, are an example of self-aggregation.

- Federal and State Government Agencies-As large purchasers of power, federal and state agencies may be interested in aggregating their loads to obtain price breaks or to reduce procurement costs. Some government agencies, such as those involved in environmental or natural resource protection, may be interested in purchasing green power for its public environmental benefits. Like local governments, federal and state agencies are typically involved in self-aggregation.

- Third Party Buyers'Agents or Brokers - Private, for-profit companies may serve as buyers' agents or brokers in markets where there is enough margin to make such transactions profitable. Typically, these for-profit companies focus on achieving cost savings for customers as opposed to offering differentiated electricity products, such as green power. These groups typically form buying pools.

- Internet Aggregators - Several private companies have formed Internet-based buying pools to aggregate small electricity purchasers and offer these customers price savings. Web-based aggregation could prove to be an inexpensive way to form buying pools, although experience with these organizations has been limited to date. Some energy providers sell power primarily via the Internet but do not otherwise emphasize aggregation any more than other competitive providers. In this report, we have focused on Internet companies that act as buyers' agents, organizing buying pools.

- Energy Cooperatives - In newly competitive markets, energy cooperatives offer a variety of benefits and services to small customers, including cost savings, consumer protections, energy efficiency services, reliability and quality of service improvements, and renewable energy options. These cooperatives are generally energy providers rather than buyers' agents and fall under the category of member-based aggregation.

- Community Choice - Municipalities may be interested in aggregating residential and business customers in the community to help small customers achieve savings in a competitive market. The ability of cities to aggregate their members typically depends on the policies and regulations that have been adopted as part of electricity restructuring. Municipalities offering this service could do so either as buyers' agents or as providers. Community choice is an example of automatic aggregation.

- Default Generation Service - Default service, or the standard offer, is also a form of aggregation, because customers who do not select a competitive power supplier are ultimately grouped with others 
in this category. A green power option could be included as part of the standard offer. This type of aggregation is another form of what we term automatic aggregation.

We discuss each of these in turn in the following sections.

\section{Business and Industry Associations}

Existing business associations were among the first to aggregate electricity loads. There are hundreds of these organizations located in each state. Some examples of business groups that have served as electricity aggregators are chambers of commerce; universities; technology councils; farm bureaus; and associations of retailers, food merchants, and manufacturers. Most of the groups identified in this survey are active in California, Pennsylvania, Illinois, or New Jersey. A few have focused on purchasing green power, although most have concentrated on reducing their members' electricity costs. Below, three rather different types of industry associations are profiled; only the first of these was involved in aggregating members to purchase green power.

\section{Green Restaurant Association}

The California Green Restaurant Association is a San Diego-based organization formed in 1990 to help restaurants and their customers minimize their environmental impacts. In the fall of 1999, the group formed an alliance with green power marketer Commonwealth Energy to encourage its 60-some member restaurants to purchase green power. The group also provided information on green power options to its mailing list of more than 10,000 customers. ${ }^{1}$ The association selected Commonwealth Energy as the preferred provider because the company was offering the least-expensive $100 \%$ green power product at the time. Commonwealth was able to offer renewable power at a discount to default rates, because of subsidies available from the California Energy Commission (CEC) for qualifying customer renewable energy purchases. In this case, the Green Restaurant Association acted as an affinity-based aggregator by endorsing a green power provider and encouraging its members to switch to green power. ${ }^{2}$ As a result of the Green Restaurant Association's endorsement, about one-sixth of its member restaurants switched to green power.

\section{California Universities}

In 1998, California State University (CSU), the nation's largest system of higher education, and the University of California (UC), the nation's largest public research university system, aggregated their power purchases. Shortly after the California market opened to competition, the organizations entered into a four-year contract with Enron Energy Services to purchase power for all 22 CSU campuses, the 9 UC campuses, and other affiliate facilities. Under the agreement, the universities together achieved savings of about $\$ 15.7$ million over four years. Enron also agreed to work with the university systems to realize greater savings by reducing energy consumption. The universities began the process of aggregating their loads about two years before the market opened to competition. At that time, the organizations believed that green power would be too expensive to consider. However, the universities may consider purchasing some green power in the next round of contract negotiations, although cost savings will continue to be a very important factor in any power purchase agreement (Enron 1998; Dayenko 2000).

\footnotetext{
${ }^{1}$ The Green Restaurant Association can be found on the Web at http://www.dinegreen.com.

${ }^{2}$ As an affinity-based aggregator, it plays a similar role to Real Goods and the Redwood Alliance, which encourage their customers or members to purchase green power from Green Mountain Energy.
} 


\section{$\underline{\text { New Jersey Business \& Industry Association }}$}

The New Jersey Business \& Industry Association (NJBIA)—an employer association with more than 16,000 member companies representing manufacturers, service providers, retailers, wholesalers, builders, and engineers - is another example of an existing business association that has made an effort to aggregate its members' power purchases. As a group, its members employ more than 1 million peopleone-third of the state's private-sector workforce. Three-quarters of the members are small companies with fewer than 25 employees. To take advantage of customer choice, NJBIA launched an energy buyers' pool called Power New Jersey ${ }^{\mathrm{TM}}$. Through Power New Jersey, NJBIA negotiated advantageous contract terms on behalf of its members with NewEnergy and Power Direct, two subsidiaries of AES Corporation, to supply electricity to the association's member companies. NJBIA members contract directly with these suppliers to purchase energy. About 1,000 have done so. NewEnergy will serve large energy users (members whose electric bills exceed \$4,000 per month) and Power Direct will serve small energy users (members who spend less than $\$ 4,000$ per month on energy). Member companies are expected to achieve savings of $5 \%$ to $20 \%$ off the electrical generation portion of their bill, depending on the size of the company, their energy profile, and their geographic location. The NJBIA sought only the lowest price for electricity and did not seek a green power option. It is up to individual members to negotiate directly with the suppliers if they want additional or alternative services. One of the suppliers, Power Direct, was offering the option of paying $\$ 0.008 /$ kilowatt-hour $(\mathrm{kWh})$ extra to retire emission allowances of sulfur dioxide $\left(\mathrm{SO}_{2}\right)$ and oxides of nitrogen $\left(\mathrm{NO}_{\mathrm{x}}\right)$; however, few if any members purchased this option. NJBIA is considering expanding eligibility for Power New Jersey to the employees of member companies, and they may be more receptive to green power. Their interest could also motivate their companies to buy green power.

\section{Assessment}

Typically, business aggregation groups are not likely to be good candidates for green power because they focus on saving money. The decision to buy green power tends to be an individual, not a group, business decision - one motivated by individual company values, feelings of civic responsibility, employee morale, and (for larger firms) public relations. Many groups may need to be educated about the benefits of purchasing green. Nevertheless, business groups or affiliations with a specific sustainability purpose, such as the Green Restaurant Association, may be receptive to green power. Universities have also been active in aggregating loads to achieve cost savings. Given that universities are often interested in sustainability, they may be good candidates for purchasing green power. However, they are also often faced with budget constraints and may need to find cost savings to offset the higher cost of green power.

\section{Religious Organizations}

A number of faith-based organizations are aggregating the loads of both church facilities and individual members to purchase green power. Their interest is based on a belief that they have a responsibility as stewards of all of God's creation, including the natural environment. Global warming is a concern for many of these groups, as is air quality. The Episcopal Church has been particularly active in spearheading many of these efforts, although several of the aggregation groups formed to date are multi-denominational or interfaith groups. Most of the recent efforts to encourage churches and their members to purchase green power have taken place in California and the Northeast, although churches have also been active proponents of green power in other regions of the country, even areas that are not currently open to competition. For instance, Ebenezer Baptist Church in Texas encourages members to participate in Austin Energy's noncompetitive green power program, GreenChoice, and a number of churches of various denominations participate in Public Service Company of Colorado's Windsource program. However, 
most of the larger scale efforts have been undertaken in competitive markets. We describe several of the more active faith-based aggregation groups below.

\section{Episcopal Power \& Light}

Episcopal Power \& Light is an initiative created to respond to concerns about global climate change. The effort has been focused on California and New England. In California, Episcopal Power \& Light has a contract with Green Mountain Energy whereby Green Mountain will rebate \$250 to any church that signs up for one of Green Mountain's products, and will pay \$35 to a church for each parishioner household that signs up. Of the 450 Episcopal churches in California, 70 have signed up. However, many churches are served by municipal utilities where customers don't have a choice, so, effectively, only about 350 churches are eligible to switch. In Los Angeles, 20 churches signed on with the Los Angeles Department of Water and Power's green pricing program. Other churches are signing up with other competitive providers, not just with Green Mountain. Most churches are signing up for the cheapest green product; however, individuals are signing up for the greener products. Although it is difficult to keep track, close to 1,000 parishioner households have signed up with Green Mountain alone, and others have probably gone with a different supplier. In the Northeast, Episcopal Power \& Light is still searching for a supplier in Massachusetts and Connecticut. This is complicated in Massachusetts, where the low standard offer, or default generation price, is too low to attract many suppliers. But the potential is high. In eastern Massachusetts alone there are about 190 Episcopal churches, and about the same in Connecticut, for a total of almost 400 churches.

\section{$\underline{\text { Maine Interfaith Power \& Light }}$}

Maine Interfaith Power \& Light announced itself early in 2000. After initial positive response to newspaper coverage, it incorporated and received a license from the Public Utilities Commission as an independent electricity aggregator. To demonstrate its ecumenical approach, it includes representation from the Maine Council of Churches, the Episcopal Diocese of Maine, the Maine Conference of the United Church of Christ, and the New England Conference of the United Methodist Church. In contrast to Episcopal Power \& Light's approach of obtaining an agreement with a supplier and then seeking adherents, Maine Interfaith Power \& Light has begun obtaining church and individual expressions of intent. Once these are secured, it will solicit proposals from suppliers. It hopes to offer a product that improves on the only green product currently available in the state, in terms of both environmental quality and price, although the latter is definitely a secondary consideration.

\section{Partners for Environmental Quality}

In New Jersey, Partners for Environmental Quality links congregations of the Episcopal and Jewish communities, and is seeking participation by the Roman Catholic diocese. It was started seven years ago to deal with environmental issues, in part by purchasing in quantity for the 100 participating congregations in and around Morris County. The business offices of the churches have been working toward aggregation of electricity purchases with the goal of lowering prices. Now, Partners for Environmental Quality is trying to shift the focus to obtaining a green power option. However, it is struggling with the process, because many of the people in purchasing positions do not have much knowledge about energy and the environment, or about how to integrate green power into an electricity purchase. After considerable effort, it has negotiated a one-year arrangement with Green Mountain Energy similar to that of Episcopal Power \& Light in California. Green Mountain will pay each congregation $\$ 20$ for every household that signs up with Green Mountain. Perhaps more important, Green Mountain will devote two staff members to coordinate the outreach efforts of a volunteer network. This would help overcome the shortage of human resources that nonprofits typically face. Partners for 
Environmental Quality would rather not align itself with a particular green power provider, but given that Green Mountain is currently the only green power marketer in New Jersey, it has agreed to partner with them, at least for the time being (Vilas 2000).

\section{Assessment}

Religious groups offer fertile ground for green power sales. They are large, many are governed through a hierarchy that is influential and easier to target, and there is a religious rationale for responsible environmental behavior. Faith-based groups are adopting two primary strategies for obtaining green power. Some groups (Episcopal Power \& Light and Partners for Environmental Quality) are teaming with green power marketers to obtain special deals. Others (Maine Interfaith Power \& Light) plan to solicit proposals for green power supply after garnering interest among their members. It is too early to determine which strategy is more effective; market characteristics, such as the number of marketers, the type of products available, the cost, and the renewables supply, may affect the decision to adopt a particular approach. Some groups may also face difficulties in procuring a supplier, because many of the people in purchasing positions do not have the requisite knowledge about energy and the environment, or about how to integrate green power into an electricity purchase. Generally, faith-based groups are still grappling with the question of how best to educate their members. Although some outreach is necessarily done church by church and congregation by congregation, some participants believe that it is more efficacious and cost-effective to work through institutional leadership and get the leaders on board first. Individuals, no matter how enthusiastic, have no power to make commitments for their churches. Even receptive organizations require significant member education to have much impact. Interfaith efforts or efforts that encompass other social justice groups may be preferred because they will create a bigger impact; however, they can also take more coordination and perseverance.

\section{Local Governments and Schools}

Local governments and school districts may be interested in aggregating their electricity purchases to obtain a better rate, reduce transaction costs, or purchase power generated from sustainable energy sources. Often these entities have regional associations (e.g., the Association of Bay Area Governments [ABAG]) that, in some cases, conduct bulk purchasing for members. We have identified a number of local governments in California, New Jersey, and New England that have considered aggregating their electricity purchases. In California in particular, where state subsidies have driven down the cost of renewable energy, a significant number of cities have opted to purchase green power. However, the California experience may not be applicable in other states, given the unique market conditions there. ${ }^{3}$ In addition, recent price volatility in the California market may put some of these purchase agreements at risk. Below, we describe the experience of several local government organizations in California and Illinois and one bulk-purchasing group representing schools in Pennsylvania.

\footnotetext{
${ }^{3}$ The CEC offers a customer credit, currently set at $1 \notin / \mathrm{kWh}$, for qualified purchases of renewable energy. The availability of the credit has driven down the cost of green power, and in early 1999 it was sold to customers at a discount to default rates. Municipalities have been eligible to receive credits for qualified purchases. However, according to a new state law extending the system benefits funds, in the future, municipalities will not be eligible to receive these customer credits.
} 


\section{Municipalities}

\section{City of Santa Monica}

In July 1998, Santa Monica became the first city in California to commit to green power when the city council directed city staff to pursue the purchase of renewable energy to power City Hall and other city facilities. The city then issued a request for proposals (RFP) for 21 million $\mathrm{kWh}$ of renewable power to supply the city's annual municipal load. In March 1999, the council approved a one-year contract with Commonwealth Energy to purchase five megawatts (MW) of geothermal power, making it the first city to switch all city facilities to $100 \%$ green power. The city agreed to pay a $5 \%$ premium, (about $\$ 140,000$ more annually) for the electricity. The city has since extended the contract for the second year; the original contract included an option to extend the contract for four additional years. Initially, the power was supplied from existing geothermal power plants at The Geysers field in Sonoma County; however, Commonwealth agreed to provide future power from new geothermal power plants developed near the Salton Sea in Imperial County. In recent months, Commonwealth reverted to supplying the city with existing geothermal power as a result of price volatility in the California market and the nature of Commonwealth's contract with Calpine for the Salton Sea geothermal project output. In addition to its municipal purchases, Santa Monica initiated a public education campaign to encourage residents and businesses to become more energy efficient and to switch to a green power provider (City of Santa Monica 1999; Munves 2001).

\section{Association of Bay Area Governments}

ABAG is an organization comprising 59 cities, counties, and public agencies throughout northern California with a peak load of about $63 \mathrm{MW}$. When the California market opened to competition, ABAG formed a power purchasing pool, ABAG Power, to purchase energy at a discount, and to provide power scheduling and billing services for participating agencies. Given that the organization's mission was to obtain cost savings for its members, ABAG Power was primarily interested in green power that could be obtained at a discount or perhaps at the same cost as system power. In August 1999, ABAG Power became a registered renewable energy provider with the CEC and began purchasing green power for 35\% of the participating agency meters that were eligible for renewable energy credits offered by the CEC. Because of the availability of the credits, ABAG was able to save on its green power purchases-it initially expected to achieve savings of about $\$ 1$ million annually. However, in the summer of 2000, ABAG Power, like other California suppliers, struggled with skyrocketing wholesale electricity prices that threatened to wipe away these savings. To stabilize its energy costs, in September 2000 ABAG Power entered a long-term, fixed-price power purchase agreement with Calpine Corporation for 30 to 40 MW of renewable energy generated primarily at the Geysers geothermal plants in the northern part of the state. As a result of the fixed-price contract, ABAG Power estimates that it saved more than $\$ 2$ million on energy purchases in November alone (as opposed to purchasing power through the state power exchange). It also saved another $\$ 1.1$ million by receiving CEC credits for its qualifying renewable energy purchases for the year (Finnegan 2000; ABAG Power 1999; 2000).

\section{City of Oakland, California}

In June 2000, the Oakland City Council unanimously approved a contract to purchase green power to meet $100 \%$ of the city's municipal electricity needs, making it the largest municipal green power purchaser in the country. In response to an RFP issued in November 1999, the city selected ABAG Power to provide approximately $9 \mathrm{MW}$ of green power, including 5\% from new renewable resources. Under the contract reached between the two parties, the amount of power supplied from new renewable resources will increase to $20 \%$ by 2004 if the city extends the initial 18 -month contract with ABAG Power. 
Initially, the green power purchase added about $\$ 70,000$, or $1.8 \%$, to Oakland's $\$ 4$ million annual electricity bill. After the first year, the price premium will rise to $2.5 \%$ or $3.0 \%$ because of reductions in a state credit for customer purchases of renewable energy. As part of the solicitation, Oakland asked bidders to participate in a public outreach effort designed to encourage the city's residential and commercial customers to buy green power; however, the winning bid focused only on supply and did not include any outreach activities (Wentworth 2000).

\section{City of Chicago/Local Government Power Alliance}

With the opening of the Illinois electricity market to competition, the city of Chicago and 47 other local government agencies formed the Local Government Power Alliance to aggregate electricity purchases. In 1999, the group - which includes the city of Chicago, the Chicago Transit Authority, the Chicago Park District, and selected city colleges was able to lower electric costs by more than $\$ 10.6$ million, or about $10 \%$, through consolidated billing. In July 2000, the alliance issued a request for services (RFS) to electricity suppliers for about $400 \mathrm{MW}$ of electric power. Of the total load, the city of Chicago consumes about 200 MW, the Chicago Transit Authority takes another 100, and the 46 other agencies use the remainder (City of Chicago 2000). The RFS called for bids that would lower costs for each member of the purchasing group and generate $20 \%$ of the power, or $80 \mathrm{MW}$, from renewable sources by 2005 . According to the schedule outlined in the RFS, the amount of green power would start at $3 \%$ of the total purchase in 2001 and increase to $20 \%$ by 2005 .

\section{Schools}

\section{Pennsylvania Energy Consortium}

Pennsylvania Energy Consortium (PENCON) is a nonprofit corporation founded to facilitate cooperative purchasing of electricity and other energy- and utility-related products and services. PENCON coordinates electricity purchase for school districts, government municipalities, and public libraries. Founded in 1997 in Milton, Pennsylvania, PENCON included 242 of the state's school districts, 42 municipalities, and 29 other nonprofit organizations as of early 1999. Membership is open to public school districts, local vocational technical schools, intermediate units, counties, municipalities and other agencies, colleges and universities, nonpublic schools, churches, volunteer fire companies, and other qualifying nonprofit companies. Annual membership cost is $\$ 25$ per year and $0.025 \phi / \mathrm{kWh}$ of electricity purchased under this program. The supplier, PP\&L Energy Plus, will contribute to an education initiative fund on behalf of educational members, provide individual account managers for all members, issue a semiannual savings report, and host an annual membership meeting and speakers. There has been some discussion of green power at PENCON but the group has yet to move forward with a purchase (Hanger 2000). The leaders of PENCON are looking primarily for lower costs and do not have much of an environmental perspective. As a result, information about the environmental impacts of electricity and the benefits of green power is sparse, and an understanding about the green market and green products is lacking. No serious thinking has been done about how to incorporate a green percentage into the products PENCON offers. The biggest hurdle appears to be a shortage of human capital to address the issue.

\section{Assessment}

Municipal agencies and schools have shown interest in purchasing green power, and as politically responsive organizations, they may continue to lead in this area. One of the main motivators is their interest in leading by example to encourage residential customers and community-based businesses to buy green power. Furthermore, municipalities that have created "sustainability initiatives" may view green power purchasing as one way to meet these objectives. In other cases, cities may only be interested in 
taking action if there is a well-organized environmental constituency or if voters are known to place a high value on environmental protection. One issue that both municipalities and schools struggle with is cost - these organizations typically have limited budgets and rely on tax revenues. However, they may be able to overcome the cost barrier by offsetting the premium. This could be accomplished through instituting energy efficiency improvements or realizing cost savings by selecting a competitive power supplier. The experience of ABAG Power suggests that long-term contracts negotiated as part of aggregated electricity purchases may also offer protection against price fluctuations in wholesale markets.

\section{Federal and State Government Agencies}

As large electricity purchasers, state and federal governments are well positioned to aggregate agency loads to purchase electricity. Both federal and state governments typically have purchasing agencies that are responsible for procuring a variety of goods and services for member agencies; thus, they have procurement methods already in place for purchasing electricity competitively. By purchasing power for many or all agencies, state and federal governments can reduce transaction costs, negotiate better rates, and perhaps, purchase power generated from cleaner sources. In competitive markets, both state and federal agencies have purchased electricity from competitive power suppliers, and in some cases, these purchases have included green power.

\section{Federal Government}

Through Executive Order 13123, the federal government - the largest purchaser of electricity in the United States - is encouraged to purchase electricity generated from renewable resources, even if it is more expensive than electricity generated from conventional sources. ${ }^{4}$ The order, which was issued by President Clinton on June 3, 1999, calls for federal agencies to use energy efficiency strategies and renewable energy technologies to cut emissions of greenhouse gases $30 \%$ by 2010 . It specifically states that "each agency shall strive to expand the use of renewable energy within its facilities and in its activities by implementing renewable energy projects and by purchasing electricity from renewable energy sources." Renewable resources are defined as solar, wind, geothermal, and biomass sources. Agencies are also instructed to submit funding requests to the Office of Management and Budget to achieve the goals outlined in the order, which may enable agencies to purchase green power at a premium.

Facilities owned and operated by the U.S. Department of Energy (DOE) have an additional incentive to purchase green power as a result of a recent Secretarial Directive. In April 2000, Secretary of Energy Bill Richardson directed DOE to purchase $3.0 \%$ of its electricity from non-hydro renewable energy sources by 2005 and $7.5 \%$ from those sources by 2010 . As a result of this directive and the broader executive order, some examples of aggregated green power purchases by the federal government now exist.

\section{U.S. General Services Administration}

In March 2000, the U.S. General Services Administration (GSA), the federal government's purchasing arm, completed the first competitive purchase of renewable energy by federal agencies in the eastern United States. GSA entered into an agreement with the Energy Cooperative Association of Pennsylvania (ECAP) to purchase Green-e certified renewable electricity for eight government accounts in Pennsylvania. GSA will purchase 2.7 million kWh annually of the ECAP's 100\% renewable energy product, EcoChoice, comprised of power generated from landfill gas and small hydro resources, to serve the accounts, which include the National Park Service's Liberty Bell operation and the U.S.

\footnotetext{
${ }^{4}$ Executive Order 13123 can be found at http://www.eren.doe.gov/femp/aboutfemp/exec13123.html
} 
Environmental Protection Agency (EPA). The green power purchase, which was undertaken in an effort to comply with Executive Order 13123, was negotiated as part of a larger GSA electricity procurement and represents less than $1 \%$ of total contracted power. The extra cost of the green power varied by utility service territory, but the overall premium was, on average, less than $5 \%$ above default rates. The agencies were able to offset the extra cost of the green power and collectively save about $\$ 1.1$ million on the total purchase (GSA 2000).

GSA is also in the final stages of negotiating a green power purchase as part of a multi-agency electricity purchase agreement in New England.

\section{U.S. Postal Service}

In April 2000, the U. S. Postal Service (USPS), the largest federal consumer of electricity other than the military, aggregated its own loads and entered into a contract with green power marketer Go-Green.com to purchase renewable power for more than 1,000 facilities in California. Under the contract, the USPS committed to purchase about 30 million $\mathrm{kWh}$ of renewable power annually for three years. The agency was able to purchase the green power for its California facilities without raising its overall electricity costs because of, in part, the availability of state subsidies for renewable energy purchases. ${ }^{5}$ However, as a result of extreme price fluctuations in the California wholesale electricity market in the latter part of 2000, Go-green.com encountered cash flow difficulties that forced the company to break the contract and turn the agency back to its default supplier. As of January 2001, the USPS was seeking another green power supplier to take over the contract. (USPS 2000; Levinson 2000; 2001).

\section{$\underline{\text { U.S. Environmental Protection Agency }}$}

The EPA has purchased green power for a number of individual facilities. In fact, EPA was the first federal agency to purchase green power from a competitive power supplier when it signed a contract for $100 \%$ renewable power for a laboratory in Richmond, California (Sacramento Municipal Utility District [SMUD] 1999). The agency entered into a three-year agreement with SMUD to purchase Green-ecertified power to serve the laboratory's electric load of 1.8 million kilowatt-hours per year. At the time of the purchase, the green power was estimated to cost EPA about $\$ 19,000$ per year more than purchasing system power, a premium of about $1.0 \notin / \mathrm{kWh}$. In addition, EPA entered into an agreement with the Bonneville Environmental Foundation (BEF) to purchase power from new wind resources to supply a portion of the agency's Northwest power needs. EPA negotiated a 10-year agreement with BEF to purchase about 2.1 million kilowatt-hours $(\mathrm{kWh})$ of wind power annually at a premium of $2.2 \mathrm{c} / \mathrm{kWh}$. The premium will be used to support the installation and operation of at least one, new $700-\mathrm{kW}$ wind turbine, which would generate enough power on an annual basis to serve EPA's Manchester Laboratory in Port Orchard, Washington. EPA also recently negotiated a contract to purchase green power for a laboratory facility in Massachusetts. Although these purchases are not examples of aggregated purchases, they are included here because the EPA's early experience may offer lessons for other agencies interested in purchasing green power through aggregated federal procurements.

\section{Federal Agencies in Colorado}

The first effort to conduct an aggregated purchase of green power in a state with a regulated electricity market came when 30 federal agencies located along the Colorado Front Range made commitments to purchase more than $10 \mathrm{MW}$ of wind energy. Some of the agencies plan to purchase the power from their electric utilities through green pricing programs. Others interested in procuring green power at a lower

\footnotetext{
${ }^{5}$ The CEC currently offers a "customer credit" of $1 \notin / \mathrm{kWh}$ for qualifying purchases of renewable power.
} 
rate plan to purchase it through the Western Area Power Administration (WAPA). WAPA plans to issue an RFP in early 2001 to purchase green certificates ${ }^{6}$ representing approximately $10 \mathrm{MW}$ of renewable power to serve the participating agencies. The agency hopes to procure the certificates, which will represent the environmental attributes of each megawatt-hour generated by the renewable facility, at a price premium less than the $2 \notin / \mathrm{kWh}$ to $3 \notin / \mathrm{kWh}$ charged by local utilities for wind power through their green pricing programs. Given that the RFP has not yet been issued, it is unclear, at this time, what premium participating agencies will pay. Many of the agencies plan to work with DOE to identify and implement energy efficiency projects to try to offset the higher cost.

\section{State Government}

\section{Pennsylvania Department of General Services}

In March 1998, Pennsylvania Governor Tom Ridge signed an executive order establishing the Governor's Green Government Council to put "environmentally sustainable practices into state government's planning, policymaking and regulatory operations.", One of the council's first targets was electricity consumption, perhaps because the executive order coincided with the opening of the state's electricity market to competition. As a result, the Pennsylvania Department of General Services (DGS) undertook an effort to purchase green power for more than half a dozen state government accounts. To accomplish this, in the fall of 1999, the DGS issued an RFP with a provision calling for $5 \%$ of the agencies' total annual purchase to be supplied by renewable resources. Renewable resources were defined broadly to include large hydropower systems, fuel cells, and all biomass resources (including municipal solid waste), because of concerns over the limited supply of renewables in the state. The $5 \%$ target was selected because it was politically feasible and it was thought to be achievable given the limited supplies. Only one bid was submitted in response to the RFP and it was rejected as too costly- the power would have cost $9 \notin / \mathrm{kWh}$, or more than twice the cost of conventional power. Consequently, the state initiated discussions with individual green power providers, eventually negotiating a contract with Green Mountain Energy Company to purchase 37 million kWh annually of hydropower and a small, unspecified amount of wind power from Green Mountain's new 10-MW Pennsylvania wind project. The contract set the purchase price at $5.8 \notin / \mathrm{kWh}$, a premium of about 1.6 cents over the state's conventional power purchases. All the agencies involved in the aggregated purchase paid a fraction of the premium - the accounts that actually received the power were selected for their size and other load characteristics. Despite the green power premium, the agencies were able to save collectively about $\$ 1.7$ million on their energy costs compared to costs prior to competition. In October 2000, the DGS extended its initial contract with Green Mountain Energy for a second year (Davidson 2000; Green Mountain Energy 2000a; 2000b).

\section{Assessment}

Federal and state governments can have a significant impact on green power demand. The federal government could play a particularly important role because it is the largest purchaser of electricity in the United States and because it has some authority, through Executive Order 13123, to purchase renewable electricity even if it is sold at a premium. Based on recent experience, federal and state agencies appear more likely to purchase green power if it is consistent with the organization's mission, if the political climate is favorable, or if a sustainability or renewable power initiative is in place. Agencies have demonstrated that it is possible to aggregate purchases in both regulated and competitive electricity markets. In regulated markets, agencies may have less leverage to negotiate price savings with utilities

\footnotetext{
${ }^{6}$ Green power certificates represent the environmental benefits of generating electricity using renewable energy. These environmental benefits are unbundled from the commodity electricity and traded separately from the energy. ${ }^{7}$ A description of the Green Government Council can be found at http://www.gggc.state.pa.us/news/gcreates.html.
} 
offering green pricing programs than they would when purchasing from a competitive supplier. Theoretically, some savings should be available, because most utilities include marketing costs in the premium of green pricing programs. However, in reality these savings may difficult to negotiate. As an alternative, agencies may be able to negotiate lower prices by purchasing green power certificates without actually taking delivery of the underlying electricity. This would allow the purchase of green power attributes from remote locations. In competitive markets, savings gained by switching suppliers can often be used to purchase a cleaner power mix without raising total energy costs. It may also be possible to lower the cost of the green power portion by virtue of a bulk purchase. However, based on the limited experience to date, it is difficult to determine whether the government has achieved savings on the green power component of the electricity purchase by aggregating loads.

\section{Third-Party Buyers' Agents or Brokers}

Buyers' agents solicit and manage energy commodity purchases for one customer (if very large) or groups of customers. Their objective is usually to obtain electric service at the lowest possible cost, because they typically earn their commissions from a percentage of the savings relative to the default service price. None of the agents or brokers identified in this survey offered a green power option. Two of the groups are described below.

\section{AES New Energy (Formerly National Energy Choice)}

In February 2000, AES New Energy purchased National Energy Choice, a group that was managing transactions between multiple energy users and power suppliers, representing the buyers. It produced savings by pooling large groups of commercial, institutional, and municipal customers. For example, in 1999 National Energy Choice offered savings of 5\% to 8\% of the utility standard-offer supply price for its clients, and savings from energy efficiency measures were also available. The energy efficiency program began with an energy survey to determine how a customer is using energy, including electricity, natural gas, water, steam, and oil. The survey was guaranteed to identify savings for the customers. As National Energy Choice, the group obtained several hundred customers, which collectively represented about 9,000 meters and almost $200 \mathrm{MW}$ of power. AES New Energy is still serving these customers, which include the Massachusetts Municipal Association's MunEnergy program, the Massachusetts Extended Care Federation, the Massachusetts Chambers Collaborative (a coalition of 12 chambers of commerce in eastern Massachusetts that has more than 11,000 members), the New England Newspaper Association, Hoyt Cinemas, the Connecticut Association of Health Care Facilities, the Connecticut Conference of Independent Colleges, and the Rhode Island Association of School Committees.

\section{Metromedia Energy}

Another buyers' broker aggregating customers is Metromedia Energy, which operates in New York, New Jersey, Pennsylvania, and Massachusetts. It is independent of any energy wholesaler or utility. Formerly CPM Energy, Metromedia Energy serves customers of Con Edison in New York, PECO in Pennsylvania and customers in Massachusetts. Like some of the Internet buying pools we discuss later, Metromedia Energy also offers long-distance telephone service and inducements such as movie tickets, restaurant discounts, and admission to Metrostars soccer games at Giants Stadium in New York. Metromedia Energy is compensated solely out of savings accrued by each group member individually, in an amount equal to $25 \%$ of actual savings. 


\section{Assessment}

Buyers' agents are possible sources of green power purchasing, although not likely for aggregate purchases. ${ }^{8}$ In this review, no third-party buyers' agents were identified that engaged in green power brokering, except for the Internet aggregators that we cover next. Perhaps this is not surprising because they find profits in cost savings, which are usually measured against the default service price. If an agent were engaged to procure green power for a group, some standard green power cost baseline would have to be agreed upon, or compensation would have to be based on some criterion other than cost savings.

\section{Internet Aggregators}

Internet energy providers have multiplied rapidly in just the last year or two. A quick scan of literature and news articles turned up beMANY.com, BmarkEnergy.com, BrightOptions.com, ChooseEnergy.com, EnergyGateway.com, Energyland.com, Essential.com, LowerMyBills.com, OmniChoice.com, OnlineChoice.com, SmartEnergy.com, Utility.com, and Wattagemonitor.com. Of these, only a few are true aggregators, helping consumers to maximize their buying power by joining free, no-obligation purchasing pools over the Internet. ${ }^{9}$

Specifically, beMANY.com, BrightOptions.com and OnlineChoice.com pool large numbers of consumers and then solicit offers from suppliers to get the best possible price. Consumers then decide individually whether to accept the offer. (Once a pool is established and has a supplier, the pool may be open to new customers at any time.) In this way, these Internet aggregators are much like the third-party buying agents described above, except that they rely on the Internet to aggregate, and they make their money in a different way.

They do not charge fees to consumers; instead, they get paid referral fees from electricity suppliers. In addition to using volume to reduce costs, on-line brokers reduce the cost of customer acquisition and billing. Obtaining a new customer can cost traditional electricity companies anywhere from $\$ 35$ to more than \$200 (Johnson 2000; Reeves 2000). In fact, some firms have even stopped adding residential customers because they are unprofitable (Tanaka 2000). In contrast, Internet companies can advertise, recruit, and service customers relatively cheaply. In addition, they cross-sell multiple services (natural gas, telecommunications) through buying groups to add to their revenue streams. Internet providers also save money by eliminating traditional call centers and by not producing and processing paper bills. ${ }^{10}$ These savings have enabled Internet aggregators or providers to offer the cheapest electricity in most deregulated markets.

\section{ElectricityChoice.com}

ElectricityChoice.com is an Internet aggregator, or buying pool, operated by Pittsburgh-based OnlineChoice.com. It was launched in August 1999 and has since been followed by GasChoice.com, HomeSecurityChoice.com, TelephoneChoice.com, and GasolineChoice.com, all buying groups of OnlineChoice.com. Participating suppliers pay a $\$ 25$ fee for every customer enrolled by ElectricityChoice.com. In some cases, the supplier may be another Internet-based company.

\footnotetext{
${ }^{8}$ Individual firms looking for green power might well utilize a buyers' agent, but this exception is not consistent with our focus on group purchasing behavior.

${ }^{9}$ The others are either retail suppliers that buy electricity at wholesale and resell it or "infomediaries" that help consumers get information on various electric suppliers.

${ }^{10}$ On-line billing may be a deterrent to some. Consumers get no paper bill, although they may receive e-mail notification, and checks are not accepted for payment. Instead, payments must be made electronically, either by an automatic monthly debit from a checking account or an automatic monthly charge to a credit card.
} 
ElectricityChoice.com has offers available in Massachusetts, California, and Pennsylvania, and is currently adding customers to its buying pools in New Jersey and New York. It promises customers 15\% to $20 \%$ savings on energy generation. Most offers at its Web site show a $20 \%$ savings compared to the default price. As an added incentive, the company gives customers who join the energy pool a telephone calling card good for 100 minutes of free long distance and a $\$ 25$ Barnes and Noble gift certificate. As of November 2000, a little over a year after start-up, the company claims to have signed up about 15,000 electricity customers (Cohen 2000; Tomich 2000). According to the shopping guide put together by the Pennsylvania Office of Consumer Advocate (OCA), ElectricityChoice.com offers a green power product in that state, but that information was difficult to find on the company's Web site. Company officials say that very few people take the green power option (Cohen 2000). The OCA shows the green power as 50\% renewable and costing significantly more than the company's low-priced offer. The price ranges (depending on the service territory) from $6.1 \notin / \mathrm{kWh}$ to $6.46 \notin / \mathrm{kWh}$ plus a $\$ 3.95$ monthly fee, compared to a range of $2.594 \phi / \mathrm{kWh}$ to $4.52 \mathrm{c} / \mathrm{kWh}$ and no monthly fee for the low-cost power. The shopping credits or default prices in these areas are $4.8 \notin / \mathrm{kWh}$ to $5.6 \notin / \mathrm{kWh}$.

\section{Assessment}

On-line firms may not have captured much of the market yet, but their share will likely grow as customer choice spreads. Forrester Research projects that on-line electricity sales in the United States are currently worth less than $\$ 10$ billion, but could grow to $\$ 100$ billion by 2004 (Johnson 2000). With that kind of growth, Internet aggregators could aid in marketing green power, but they may have to be convinced that enough customers are looking for green power before offering that option. Typically, they have emphasized low price and billing convenience, rather than brand- and value-based green power products. Furthermore, Internet aggregation tends to reinforce the rationale of shopping for the cheapest power without consideration of the environmental impacts. However, it is easy for dot.coms to allow consumers to register their interest in green power on-line. ${ }^{11}$ In addition, it is easy for them to expand their portfolio of products, although dot.coms may not necessarily have the credibility with consumers to market green power products effectively. In the future, green power providers may work with aggregators to try to take advantage of low customer acquisition costs. In addition, dot.coms, at least the infomediary variety, may help consumers locate or identify the green power products available in their area.

\section{Energy Cooperatives}

Energy cooperatives are member-based organizations formed to offer energy services and products, such as heating oil or electricity, to consumers. These groups typically offer a variety of benefits and services to small customers, including cost savings, consumer protections, energy efficiency services, reliability and quality-of-service improvements, and renewable energy options. Many energy cooperatives have traditionally focused on helping low-income customers reduce their energy costs. Heating oil cooperatives have played an important role in supplying small consumers, particularly in the Northeast where many residential customers rely on oil to heat their homes. As more states open their markets to competition, new energy cooperatives are beginning to form to provide consumers with choices. Many of these efforts to launch new cooperatives are being spearheaded by existing cooperatives and cooperative associations. Both existing and new cooperatives have begun to offer green power options. We profile a few of these organizations below.

\footnotetext{
${ }^{11}$ If the green power interest group gets big enough, the dot.com aggregator may then solicit bids. Before soliciting suppliers, one company is looking for 10,000 on-line expressions of interest, a number that would take a long time to reach for a passive (and merely potential) green power option.
} 


\section{Existing Cooperatives}

\section{Energy Cooperative Association of Pennsylvania}

ECAP is a member-based organization originally organized to offer bulk purchasing of home heating oil to members, primarily in the Philadelphia area. Since 1979, ECAP has negotiated prices with oil dealers that are consistently $20 \%$ lower than average retail prices, saving its members approximately $\$ 200$ per year. It entered the electricity market in 1998, offering both nonrenewable and green power products in the PECO territory. Products, prices, and sources of energy have changed over time, but the cooperative still offers both. Its current green product, called EcoChoice 100, is $100 \%$ renewable and certified by Green-e. The addition of electricity to its heating oil and energy efficiency products and services has had a huge impact on membership. Before restructuring, ECAP membership stood at about 500. It is now at 7,000. Most of these new members are purchasing electricity only, although some also use the cooperative to purchase heating oil. Further, about 800 of its members (more than 10\%) are purchasing green power. In early 2000, the posted price for EcoChoice 100 was the same as the default power price $(5.65 \notin / \mathrm{kWh})$. ECAP has arranged a deal with a supplier, Mack Services Group, a 70-year-old residential heating oil supplier, for power from primarily existing landfill gas and small hydropower resources. Over the summer of 2000, ECAP stopped accepting new electricity customers because of increases in wholesale electricity prices. Recently, however, it began accepting new customers, but raised the price of its green product to $6.37 \mathrm{\phi} / \mathrm{kWh}$, a slight premium over the default power rate.

\section{Massachusetts Energy Consumers Alliance}

The Massachusetts Energy Consumers Alliance (MECA) is another organization created to offer bulk purchasing of home heating oil. Until recently named the Boston Oil Consumers Alliance, MECA serves members in Greater Boston and eastern and central Massachusetts. MECA has arranged discounts of about $20 \%$ on oil prices for its members since 1982. With the advent of electricity restructuring in 1998, MECA considered developing a green power product to serve its existing 6,000 members and also to expand its membership. Rather than market its own product, MECA decided to offer its members a green power option called ReGen developed by AllEnergy Marketing Company, a subsidiary of New England Electric System. Members would not actually switch suppliers, but for \$8.00/month ReGen promised $2,000 \mathrm{kWh}$ from new renewables generated to the grid. The charge was not included on the customers' energy bills. About 130 MECA members (2.2\%) signed up for ReGen, a better-than-average market penetration for utility green pricing programs. ${ }^{12}$ There has been very little competitive activity in Massachusetts, however, and AllEnergy is now reportedly for sale. As a result, the future of the green power product is uncertain. At this time, MECA is not trying to sell ReGen to more members, but continues to bill those members who have already purchased the product. MECA is weighing its future role in green power and customer choice for electricity. It believes that the market in Massachusetts is not ready for green power or any other competitive product at this time because of the low default service price. Once this standard offer increases, the market may be more conducive to customer switching and green power choice. MECA has concluded that it will "wait for the market to ripen."

\section{New Energy Cooperatives}

Several new energy cooperatives have begun organizing in the Northeast, spurred by the opportunity to offer customers a choice of electricity providers. These groups have grown out of a 1997 agreement between the Cooperative Development Institute, Coordinated Housing Services, and two electric

\footnotetext{
${ }^{12}$ Green pricing is an optional electricity product generated from renewable energy sources offered by a regulated electric utility. More than 200 utilities offer green pricing programs nationally.
} 
cooperatives. ${ }^{13}$ The agreement outlined a plan to work together to provide an economical, reliable, and sustainable package of energy services to a significant number of people throughout the Northeast. ${ }^{14}$ The agreement established an organizing team, now called the Northeast Energy Cooperative Regional Steering Committee, which decided to organize new cooperatives by building on organizations that shared its values.

The new organizations include cooperatives in New Hampshire (New Hampshire Consumers Utility Cooperative), western Massachusetts (Co-opPlus of Western Massachusetts), Connecticut (Connecticut Energy Cooperative), and New York City (1st Rochdale). ${ }^{15}$ These cooperatives offer, or plan to offer, energy products such as electricity (both standard and green power); heating fuels; renewable energy equipment; power quality; special payment plans; energy efficiency and conservation; and financing of energy-related improvements such as home audits, weatherization, and appliances. They have selected the North Carolina Electric Membership Corporation (NCEMC), a large cooperative serving 750,000 people, to help the project aggregate its electric purchasing power. In addition, the group hired the Cooperative Development Institute to provide information and support for entities interested in forming new cooperatives, and established a cooperative to furnish services that require economies of scale and technical expertise.

This set of interrelated cooperatives appears to offer the support systems necessary to be viable in the business of energy supply; several of them, however, still have long way to go. Two of them are now selling power-1st Rochdale Cooperative and the Connecticut Energy Cooperative. Both of these are profiled below.

\section{1st Rochdale Cooperative NYC}

1st Rochdale Cooperative NYC is a consumer-owned, not-for-profit energy and telecommunications company created in 1997 by a coalition of New York City housing cooperatives representing 50,000 households. Although it has its foundations in the housing cooperative movement, it does not "own" those customers, and must market and compete like any other supplier. Currently 1st Rochdale provides electricity service to about 12,000 families and businesses through 1,000 meters in New York City and Westchester County with service expanding soon to the larger metropolitan area.

Its mission is to: (1) lower members' total energy bills through comprehensive energy management, (2) develop energy conservation and generation strategies and renewable energy sources, and (3) deliver state-of-the-art telecommunications service. Because 1st Rochdale is owned by its customers and does not seek to make a profit, it is focusing on reducing overall consumption of electricity through bulk purchasing and energy efficiency, and on contributing to a cleaner environment through renewable resources and high-efficiency technologies. It will provide natural gas and heating oil (it acquired an oil storage terminal in November 1999), and satellite television and Internet services. It also plans to offer sustainable energy technologies, including photovoltaic (PV) systems and fuel cells, in the near future, and a grid-based green power product in 2001.

\footnotetext{
${ }^{13}$ The two cooperatives involved in the agreement are Washington Electric Cooperative and New Hampshire Electric Cooperative.

${ }^{14}$ Washington Electric Cooperative currently provides electricity to 9,000 people in central Vermont. New Hampshire Electric Cooperative provides electricity to 65,000 people across New Hampshire. Coordinated Housing Services represents 50,000 cooperative housing units in New York City. The Cooperative Development Institute has strong connections with the region's 10,000 cooperatives and credit unions that have 10 million memberships in the Northeast.

${ }^{15}$ Other cooperatives still under discussion or development include ones in Maine, Vermont, Rhode Island, eastern Massachusetts, and upper New York State.
} 


\section{Connecticut Energy Cooperative}

The Connecticut Energy Cooperative was incorporated in January 1999 "to create and maintain an economically, environmentally, and socially sustainable energy future rooted in Connecticut and responsive to the needs of its members." It offers its members one-stop energy shopping, including electricity, fuel oil, propane, and energy efficiency and telecommunications services. Its focus is on lower energy bills, not lower prices. To get itself launched, the Connecticut Energy Cooperative relied on strategic alliances with Cooperative Development Institute for strategic business planning, Cooperative Pioneers for technical and marketing support, North Carolina EMC (a large rural electric cooperative) for a 24-hour call center, and the National Rural Utility Cooperative Finance Corporation for debt financing. As a means to accelerate the creation of a green electricity market, it has also received a half-milliondollar loan from the Connecticut Clean Energy Fund. The Connecticut Energy Cooperative lacks an instant membership base with long experience with cooperatives, yet it has forged ahead and is slowly gathering members. It purchased $\$ 500,000$ in television advertising that began airing in July 2000 , and within the month had reached a total enrollment of more than 500 members. It has set a longer-term goal of obtaining 20,000 members. It also received its supplier's license in late July and switched its first customers in November 2000. The Connecticut Energy Cooperative is currently offering two electricity products:

- The ValueWatt electricity product (system power) sells for $5.25 ф / \mathrm{kWh}$, less than the standard offer of 5.5 cents in Connecticut Light \& Power's service area.

- The EcoWatt product sells for $6.5 \notin / \mathrm{kWh}$, a 1.0-cent premium in most of the state, and a 1.5-cent premium in the New Haven and Bridgeport areas. This product consists of hydro, landfill gas, and wind, and is Green-e certified.

A solar electric green power product is in the works for next year. Co-op members are also encouraged to minimize their energy use through energy conservation and efficiency, services that the cooperative will provide. The cooperative also advertises solar technologies, including PV; however, the details have not yet been fleshed out. Because the cooperative is a not-for-profit, a minimum of $20 \%$ of surplus revenues must be rebated back to members, based on their level of purchases. The other $80 \%$ will be used to subsidize the cost of energy efficiency (e.g., compact fluorescents) and the development of renewable energy.

\section{Assessment}

Existing energy cooperatives may be very good candidates for purchasing green power. Fuel oil cooperatives and other energy cooperatives are in the business of providing energy services, and thus have the knowledge and ability to offer members additional energy products, such as green power. Further, many energy cooperatives have focused on offering assistance to low-income families, and have a tradition of being socially responsible. Many of the people involved in the cooperative movement are also interested in sustainability issues, and because co-ops are democratically organized, green power may be supported. New energy cooperatives could also be important for green power. And although launching a new energy cooperative, like any business start-up, requires a lot of support, existing cooperative associations can provide support in the form of technical and financial infrastructure, energy supply procurement, billing capabilities, and call centers.

\section{Community Choice}

Consumer advocates have argued that local governments should procure electric power and related services on behalf of the residents of their communities to ensure that these customers benefit from 
competition (Asmus 1998; Marshall and Colton 1998; Rader and Hempling 2000). This process is known by a number of names, including municipal aggregation, public aggregation, community electricity franchise, and community choice. To avoid confusion with aggregation of municipal government loads (discussed previously), we will refer to it as community choice.

The major distinction with respect to community choice is between the opt-in and opt-out approaches (see text box). The biggest boost to community aggregation comes from the opt-out approach. Massachusetts included the opt-out approach in its restructuring legislation, ${ }^{16}$ and Ohio followed suit in $1999 .{ }^{17}$ In addition, federal legislation has been introduced in support of community choice that would also support the opt-out approach. ${ }^{18}$ To date, there has been limited experience with implementing community choice. On November 7, 2000, citizens of 136 towns and counties voted on the issue of community choice. More than 100 communities passed the measure to aggregate loads (Perkins 2000). Ohio opened for competition on January 1, 2001, but it is not yet known whether any of the communities will pursue a green power choice. In Massachusetts, several communities are pursuing aggregation. Below, two examples of community choice are provided — one from Massachusetts (illustrating the opt-out approach) and the other from Pennsylvania (illustrating an opt-in approach conducted by a Pennsylvania marketer in conjunction with cooperating communities).

\section{Opt-In versus Opt-Out Aggregation}

“The 'opt-in' model envisions building an energy buying group through intense community outreach and a grass-roots campaign on behalf of the municipality, knocking on residents' doors and asking each person to sign up. No customer can be included in the opt-in aggregate unless he affirmatively signs up.

"The 'opt-out' model of municipal aggregation would allow the municipality to form an energy buying group on behalf of its residents. The difference is that instead of going to each individual to ask them to sign up, the community could do it through a public town hall meeting and a public education campaign. Residents would be notified about the process, informed about the steps, and given the option to 'opt-out' of the aggregate if they so chose.

"The 'opt-out' model directly addresses [the] key problem of uncertain pool size. By obtaining the consent of the residents to aggregate them automatically, the municipality achieves the critical advantage of assembling a large and relatively certain aggregate of customers. Negotiations with potential suppliers become easier for both parties, since the supplier is assured a reasonably predictable pool of customers, and can therefore offer more attractive terms for price and service, while the municipality is spared the extraordinary burden of getting each and every resident to sign on the dotted line before the contract is negotiated. Any resident who does not want to be part of the aggregate can easily withdraw."

Source: New Jersey Ratepayer Advocate (Peretz 1998).

\footnotetext{
${ }^{16}$ Chapter 164 of the Acts of 1997, Section 247 (new Section 134).

${ }^{17}$ Ohio Revised Code Section 4928.01 and 4928.20.

${ }^{18}$ HR 2734, "a bill to allow local government entities to serve as nonprofit aggregators of electricity services on behalf of their citizens," was introduced in Congress by Rep. Sherrod Brown of Ohio and six colleagues in the House, August 6, 1999. It is referred to as the "Community Choice for Electricity Act of 1999."
} 


\section{Cape Light Compact (Opt-Out Community Choice)}

The Cape Light Compact was formed in 1997 to negotiate a power supply contract for the citizens and businesses of 21 participating towns in Massachusetts representing 185,000 customers. ${ }^{19}$ It was developed by the Cape \& Islands Self-Reliance Corporation, a nonprofit organization on the Cape since 1980, and Barnstable County. In March 2000 the compact announced an agreement with Select Energy, an unregulated affiliate of Northeast Utilities, to supply power to compact members. The deal was finally struck after the compact was able to overcome all the political obstacles and legal delays in meeting legislative requirements (see text box). Under the contract, the price for each class of customers is lower

\section{The Cape Light Compact}

The Cape Light Compact issued an RFP in August 1998 to solicit proposals for electric service. It required that the bids be lower than the standard offer in Massachusetts. (The standard offer is the default service price charged to electricity consumers who do not choose a supplier.) This was particularly difficult given that the standard offer was initially set at $3.5 \notin / \mathrm{kWh}$, a level that was below the wholesale cost of electricity. As a result, proposals were not responsive to price requirements. The standard offer, however, is set to increase slowly, and a second solicitation was issued in January 1999. This solicitation resulted in four bids that promised to beat the standard offer. After a lengthy negotiation that was complicated by competing claims to the towns' municipal government loads, a contract was finally submitted to and approved by the towns in the second quarter of 2000 .

In addition to approval of the supply contract by the towns in the compact, the state Department of Telecommunications and Energy (DTE) must also approve the compact's plan. The plan is now (as of July 2000) before the DTE, which will check to ensure that the price offered is lower than the utility company's standard offer. The price can be the same as the standard offer if it is due to the purchase of renewable energy.

Because it costs more to serve small customers, the contract allows them to be phased in as the standard-offer prices increase. Under the schedule in the contract, consumers would be phased in beginning with street lighting and large accounts in December 2000, followed by municipal and small and medium commercial accounts in 2001, and finally residential consumers in 2002. If conditions in the wholesale market prevent Select Energy from commencing service at the contract prices according to the schedule, flexible terms allow deferral of the schedule until the right supply price window appears. The compact can also shop for other supply at the same time.

Finally, the compact plans to create renewable energy and energy efficiency programs using some of the system benefits charges that all customers pay. For renewables, about $\$ 1.8$ million is paid by ratepayers of the 21 towns into the Massachusetts Renewable Energy Trust Fund. The compact must apply for these funds, however. In contrast, if the compact's energy efficiency plan is approved by the state, it will gain control of $\$ 4.5$ million that currently goes to the distribution utility to operate demand-side management programs.

\footnotetext{
${ }^{19}$ This section draws heavily from the Web site of the Cape \& Islands Self-Reliance Corporation at http://www.reliance.org.
} 
than the standard offer from the default service provider Commonwealth Electric. ${ }^{20}$ The contract also allows up to $3 \mathrm{MW}$ of green power to be included in the supply mix. Whether or not this is done depends on both the price and availability of green power. The total cost cannot exceed the standard offer price from the distribution company. ${ }^{21}$ It is undecided at this time whether the extra cost of green power, if any, would be borne by all customers in the compact, or whether it would be presented as a choice, charging a premium only to those who opt for green service. But regardless of the additional green energy requested by the compact, the supplier must also comply with the Massachusetts Renewable Portfolio Standard, which requires $1 \%$ of supplies to come from new renewables beginning in 2003 and increasing to $4 \%$ in 2009 .

\section{Allegheny Energy Supply (Opt-In Community Choice)}

Allegheny Energy Supply, an affiliate of Allegheny Power Company, has had considerable success in aggregating the residents of communities in western Pennsylvania. The Electric Choice Community Program is targeted at communities in the Duquesne Light and Penn Power service territories. Allegheny Energy Supply charges $4.3 \phi / \mathrm{kWh}$ in the Duquesne Light market and $4.6 \phi / \mathrm{kWh}$ in Penn Power's territory. Both prices are lower than the shopping credit-Pennsylvania's equivalent of the default service price. Otherwise, unlike in PECO territory, there is not much competition in these two territories. Allegheny Energy Supply will discount its prices further depending on how many members of each community sign up. The Electric Choice Community Program has been very successful from an aggregation standpoint. More than 80 communities have signed up, and typically $25 \%$ to $30 \%$ of customers in the community participate. Allegheny does not, however, offer a green power product, and is not aware of any communities expressing an interest in green power (Lantz 2000).

\section{Assessment}

Like municipal government purchases of green power, community choice has some potential to support green power purchases. Community choice, whether for green or commodity power, is more likely to be effective with the opt-out approach, but with determined action it could also work with the opt-in approach, as evidenced by Allegheny Energy. Because community choice will most often be pursued with a cost-savings objective, it may be less likely to increase demand for green power than some other aggregation approaches. However, if green power is supported, community choice could have a relatively large impact because of the number of customers aggregated.

\section{Default Generation Service}

Default generation service - also called the standard offer in some states - is provided to customers who do not choose an alternative competitive supplier voluntarily. Every state that restructures must make some provision for serving customers who do not proactively choose a supplier. Initially, this group of customers will be very large. To reduce market domination by the traditional supplier, states may order default suppliers to assign a certain portion of customers to an alternative provider, if these customers do not switch suppliers voluntarily.

For example, Pennsylvania regulators ordered that PECO essentially divest itself of $20 \%(299,000)$ of its customers by January 2001, as part of a merger settlement agreement. In response, PECO issued an RFP

\footnotetext{
${ }^{20}$ Commonwealth Electric's standard offer prices are set to increase from $3.8 \notin / \mathrm{kWh}$ in 2000 and 2001 , to 4.2 cents in 2002, 4.7 cents in 2003, and 5.1 cents in 2004.

${ }^{21}$ Presumably, the compact could offer an alternative green power product as an option if it costs more than the standard offer, and this approach may be a better strategy for addressing concerns about low-income consumers than incorporating renewables in the standard product. However, the latter strategy may ultimately support more renewable energy capacity, and thus, be better for the environment.
} 
and selected The New Power Company as the provider of "competitive default service." The terms of the award require that at least $2 \%$ of the energy must come from renewable resources. The New Power Company has also promised to offer these customers a renewable upgrade service provided through Community Energy, a small retail company that is promoting green power from wind.

\section{Assessment}

Default service offers an opportunity to include a minimum percentage of renewable energy in the supply portfolio for customers that may be switched automatically, as well as an option to offer an upgrade service to green power. It may be challenging for states to adopt such a policy, but the potential for increasing sales of green power is significant. 


\section{Opportunities and Barriers}

\section{Opportunities}

As new markets open to competition and as markets already open to competition become more active, several types of groups hold promise as green power aggregators. Recognizing that the aggregation groups considered in this report have varying goals, organizational structures, motivations, and interests in green power, we gauged the prospects for the following groups to have an impact on the market for green power.

- Energy Cooperatives. Energy cooperatives, such as fuel oil and electric cooperatives, are likely to be supportive of green power sales. Because they have experience in aggregated energy purchasing and roots in social responsibility (i.e., low-income assistance), cooperatives are strong candidates. New cooperatives may also hold potential for offering green power, but they struggle with organizational difficulties faced by any start-up business and the standard difficulty in being a retail supplier in newly evolving markets.

- Federal and State Government. Federal and state governments are likely candidates for aggregated green power purchases, especially if it is consistent with the agency's mission or if a sustainability initiative exists. Governments have experience in aggregated purchasing and appropriate infrastructure is in place. In addition, at the federal level, several initiatives encourage agencies to purchase green power, including Executive Order 13123, which calls for federal agencies to increase their purchases of renewable electricity.

- Religious Organizations. Religious groups are very good candidates for purchasing green power because of their hierarchical structure and their beliefs. The members of these organizations may be more inclined to support green power because of an interest in sustainability and a belief in environmental stewardship.

- Local Governments and Schools. Municipal governments are likely to be interested in buying green power for their own facilities, especially if they already support sustainability initiatives or they have a recognized and organized environmental constituency. However, cost issues may prohibit cities from taking action.

- Community Choice. Community choice may be difficult to implement because it will require political support, and may require a lengthy political process, but the potential impact on green power demand could be large. It is more likely to be effective if residents and businesses are automatically included in the aggregation, with the opportunity to opt out.

- Default Generation Service. To reduce market dominance by the traditional supplier, some states will require that at least a portion of all customers be served by a provider other than the local utility. States that encourage alternative providers in this way offer an opportunity to ensure that renewable energy is part of the resource mix. Because of the large numbers of customers involved, this type of aggregation has the potential to significantly increase sales of green power.

- Internet Aggregators. Internet aggregators have not yet demonstrated effectiveness in supporting green power. This group will likely experience a lot of growth as electricity providers, but they do not appear likely to position themselves as green power providers or significantly contribute to green power sales in the short term. Most have focused on offering customers cost savings. However, they 
have the ability to easily add products and options, which may allow them to offer green power as an optional service without incurring significant expense.

- Business and Industry Associations. General business associations have the ability to aggregate members relatively easily because they typically have the necessary outreach mechanisms in place. However, they are not likely to be good candidates for green power because they usually focus on saving money. On the other hand, business groups or affiliations with a specific sustainability purpose may be receptive to green power.

- Buyers' Agents or Broker. Third-party buyers' agents do not hold much potential for advancing sales of green power. Typically, buyers' agents are focused on obtaining electric service at the lowest possible cost because they usually earn their commissions from a percentage of the savings relative to the default service price.

\section{Barriers}

Although aggregation for green power faces several barriers, most are not unique to aggregation efforts. These barriers include the extra cost of green power, the need for greater education and information about green power benefits, lack of human capital to do the education, market rules that dampen competitive markets, uncertainty about the size of green power markets, the lack of human capital for organizing group-buying and green power options, and the scarcity of renewable resources for green power products in some markets.

- Higher Cost. Among the barriers to aggregation for green power is the most obvious: green power usually costs more than commodity electricity. Most aggregation efforts - especially those that have been the most successful to date- have targeted lower cost electricity, not green power.

- Need for Education and Information. In addition to a general lack of awareness about the environmental impacts of electricity and the benefits of green power, many organizations do not have adequate information about how to specify green power in their requests to suppliers. Not enough thinking has been done about how to integrate green power into the products aggregators offer to group members. Generally, the leaders of groups that might be supportive of green power are focused on lower costs and do not know much about environmental issues.

- Market Issues. The rules established for market operation vary from state to state, and can have a major influence on the competitive attractiveness of a market. Some markets discourage switching through low default service prices. This can make it impossible for suppliers to compete and make a profit. Lacking that opportunity, suppliers will not be interested in serving aggregation groups. Over time, however, these prices may change and supplier interest may increase. Other market rules and issues, such as those that follow, can affect the ability of buying groups to aggregate loads:

- The requirement for opt-in aggregation for municipal residents (which is the norm in most states) makes it more difficult to organize and to achieve a sizeable buying group load.

- Even with opt-out rules, state policy can impede municipal aggregation through additional requirements for positive affirmation of participation (with similar effect as opt-in), requiring a ballot vote by the full electorate, requiring a super-majority vote of a city council, or subjecting municipal aggregators to additional regulatory review.

- State rules for "wet signatures" as a consumer protection measure to avoid slamming can increase costs, especially to Internet aggregators whose businesses rely on avoiding the extra costs of direct mail and paper contracts. 
- The volatility of the wholesale market in which power is bought and sold before being resold to consumers can be a barrier.

- Uncertain Demand for Green Power. All new markets present uncertain demand, and new entrants into existing markets face uncertain market share. Because green power is still generally a higher cost product, however, it makes the uncertainty greater. Premium products do thrive in other markets. The challenge for green power marketers and aggregators is to present an attractive value proposition.

- Lack of Human Capital. Whether launching a new business, as with new energy cooperatives, or adding a new service for existing groups, organizing is a lot of work and is very time-consuming. Voluntary efforts have limited success. Human resources may be scarce unless start-up capital is available. In addition, aggregating customers to purchase a green power product requires a significant amount of education. Most efforts to date have suffered from a shortage of human capital to conduct the education and outreach.

- Scarcity of Green Power in the Area. The limited supply of green power available in some competitive markets may limit the ability of aggregation to be used as an effective purchasing tool. Suppliers may not have enough green power available to serve multiple loads in different states or different locations.

\section{Other Barriers}

Internet buying groups reduce costs in part by requiring on-line billing and payments; however, paying electric bills on-line, either by charging credit cards or through automatic deductions from checking accounts, may be a barrier for some consumers concerned about privacy or security.

Aggregation for electricity is a business; however, some organizations lack entrepreneurial thinking, technical experience, or environmental leadership.

Cities may have difficulty bundling energy efficiency and green power purchases to reduce overall energy costs because energy efficiency investments and electricity purchases come out of separate budgets. Other aggregation entities may find that many efficiency projects have already been implemented. 


\section{Recommendations and Conclusions}

\section{Recommendations}

Based on our discussions with aggregators, we developed a list of recommendations for those interested in establishing an aggregation group and for those with efforts under way. Aggregators can strategically position themselves to maximize customer participation and minimize aggregation costs in a variety of ways; we have listed a few of the more successful approaches.

- Aggregators can use both energy efficiency and negotiated costs savings from the competitive market to offset the extra cost of green power. For energy efficiency, aggregators could develop an agreement for these services as part of the green power deal, or they could develop the resources in house to gather data on energy use and identify energy-saving opportunities.

- Aggregation groups may be able to negotiate a deal with a green power provider that will compensate the group for customer acquisition. This could benefit the supplier by lowering acquisition costs and could benefit the aggregating group by supplying some income. It could also help fund human resources for the organizing, educating, and aggregating effort.

- If it is not possible to compete because of low default service prices, it may be better to wait until the market is more competitive and can attract suppliers. The interim period may provide a good opportunity to plan and organize before actually launching a product.

- People or organizations interested in starting up new energy cooperatives should take advantage of a network of technical support services and strategic alliances (for business planning, debt financing, product development, marketing, and call centers, for example) that allow the cooperatives to focus on organizing and acquiring members. This should increase the chance of success.

- To gain a sufficient number of customers and to be profitable, aggregators may need to have more than one product, not just a green product. This may mean offering a standard electricity product as well as other non-electric services, depending on the type of aggregator and its goals.

- Consumer and organizational education is needed to raise consciousness about the environmental impacts of electricity production. Aggregation groups need to reinforce the education messages coming from the public sector. Education should cover not only environmental issues, but should also address concerns such as reliability and credibility. Groups should take advantage of existing resources and efforts, such as those sponsored by environmental organizations, to educate their members about these issues.

- Aggregation groups should define what they mean by green power before procuring power. Otherwise, the definition may become an issue when negotiating a purchase with a supplier. Alternatively, groups could consult with local environmentalists or they could simply specify that the energy supplied be Green-e certified.

\section{Conclusions}

Aggregation does hold potential for increasing demand for green power. Although there are a wide variety of aggregation groups, with differing motivations, goals, structures, and interests in sustainability issues, many have the potential to effectively use their organizations to increase sales of green power. 
Those groups with a mission related to environmental protection or with an interest in sustainability appear to be the most likely to offer or purchase green power.

Aggregation groups can act as buying agents for their members, as providers or resellers of green power, or they can simply endorse a particular product(s). Acting in any of these roles, groups can increase access to green power, perhaps lower the cost, and offer incentives for members to participate. However, a group acting as a provider or reseller of green power may be more effective in achieving a discount for its members than one that merely endorses a green power provider. On the other hand, serving as a provider or reseller requires more sophistication and knowledge of the industry and some groups may want to shy away from the risk.

Today, the organizations that are most active in aggregating demand to purchase green power include energy cooperatives; local, state, and federal governments; and religious organizations with an interest in sustainable energy alternatives. These groups are likely to have continued success as markets become more fluid, green power supplies grow, and, perhaps, as the price of green power falls over time.

Of the groups considered in this report, some have targeted an existing member base; others, such as energy cooperatives, must obtain customers to be successful. To date, more aggregation has resulted from existing groups, particularly groups with some experience in bulk purchasing. Forming a new group comes with all the challenges of starting up a business; however, there is potential for success. At least for energy cooperatives, these technical support services and strategic alliances exist.

As markets evolve, other types of aggregators that have shown limited potential thus far may offer an opportunity to advance green power sales. For example, community choice may be effective under an opt-out framework if political obstacles can be overcome. In addition, Internet aggregators, which are expected to experience rapid growth, have the ability to easily add options, such as green power, to their portfolios; however, it remains to be seen if they will do so.

As we begin to see more activity in competitive markets and as the cost of renewable energy options decreases over time, green power aggregators will play a more prominent role in the marketplace. These aggregation groups have the potential to increase sales of green power by educating their members about the benefits, increasing options, and lowering prices. As opportunities unfold in the marketplace, existing groups and green power advocates may be able to learn from the early experience of aggregation groups to bring green power choices to a greater number of customers. 


\section{Bibliography}

ABAG Power. (August 4, 1999). "ABAG Power Delivers Green Energy to Cities and Counties in Northern California." News release, ABAG Web site:

http://www.abag.ca.gov/services/power/0802calpine.html

ABAG Power. (December 21, 2000). “ABAG Power Saves Members Millions.” News release.

Asmus, P. (January 1998). "Power to the People: How Local Governments Can Build Green Electricity Markets.” REPP Issue Brief No. 9. Washington, DC: Renewable Energy Policy Project.

Austin Energy. (August 11, 2000). "Ebenezer Church to Dedicate Solar System; Churches Lead Movement Toward Green Power." News release, Austin Energy Web site:

http://www.electric.austin.tx.us/press/ebenezer.htm

Chopra, S. (June 1, 2000). "War Stories: Sometimes Finding Investors Means Finding Yourself."

Pittsburgh Post-Gazette, Post-Gazette.com:

http://www.onlinechoice.com/us/home/body/about_us/press.asp

City of Chicago. (July 18, 2000). "Mayor Daley Announces City-Suburban Joint Power Purchase.” News release.

City of Santa Monica (February 24, 1999). "Santa Monica Council Votes to Exclusively Power City Facilities with Green Electricity.” News release.

Cohen, M. (November 11, 2000). Personal communication. See also OnLineChoice.com.

Davidson, K. (March 22, 2000). Personal communication. Penn State University.

Dayenko, P. (May 16, 2000). Personal communication. California State University.

ECAP. (March 24, 2000). Liberty Bell Turns Green Thanks to Philadelphia-Based Energy Cooperative. News release.

Enron. (February 28, 1998). "CSU and UC Sign Contract with Enron to Become Largest Direct Access Electrical Energy Customer in the Country." News release, Enron Web site:

http://www4.enron.com/corp/pr/releases/1998/ene/calstate.html

Environmental Futures, Inc., Tellus Institute, and EUA Citizens Conservation. (July 31, 1998). Feasibility of Small Customer Aggregation for the Delivery of Comprehensive Energy Services in a Competitive Utility Environment. Prepared for the U.S. Department of Energy, Chicago Regional Office.

Finnegan, D. (March 22, 2000). Personal communication. ABAG.

GSA. (March 23, 2000). “GSA Cuts Energy Costs in Pennsylvania and Delaware.” News release.

Green Mountain Energy. (January 5, 2000a). "Pennsylvania Government Nation's 1st State to Buy Green Power." News release. 
Green Mountain Energy. (October 30, 2000b). "State of Pennsylvania Renews Green Energy

Commitment." News release: http://biz.yahoo.com/prnews/001030/pa_green_m.html

Guinane, K. Group Buying Power: Meaningful Choices for Energy Consumers. Washington, D.C.: Environmental Action.

Hanger, J. (May 25, 2000). Personal communication. PennFuture.

Johnson, T. (April 23, 2000). "Web Energy Pools-Grow More Utility Customers Signing Up Online." The Star Ledger (New Jersey).

Lantz, J. (May 25, 2000). Personal communication. Allegheny Energy Supply.

Levinson, R. (October 12, 2000; January 9, 2001). Personal communication. USPS.

Marshall, P.; Colton, R. (June 1998). Aggregating Low Income Customers: Can Market-Based Solutions Fix Market-Based Problems? Minneapolis, MN: Energy CENTS Coalition.

Munves, S. (January 10, 2001). Personal communication. City of Santa Monica.

Pennfuture's $E^{3}$ (January 12, 2000). “Marketing the Commonweal.” Harrisburg, PA: Citizens for Pennsylvania's Future (PennFuture).

Peretz, B. (1998). "Community Choice Means Competition, Not Slamming." American Local Power Project, New Jersey Ratepayer Advocate. Found at www.local.org under Community Choice.

Perkins, O. (November 8, 2000). "Residents in 7 Counties OK Bulk Electricity Issue." Cleveland Plain Dealer.

Rader, N.; Hempling, S. (January 2000). Promoting Competitive Electricity Markets Through Community Purchasing: The Role of Municipal Aggregation. Washington, D.C.: American Public Power Association.

Reeves, F. (April 5, 2000). “Aiming to Help, Dot.coms Can Confuse.” Pittsburgh Post-Gazette.

Rudolph, R.; Ridley, S. (1986). Power Struggle: The Hundred Year War Over Electricity. New York: Harper \& Row.

SMUD. (June 4, 1999). “SMUD Sells Green Power to Federal EPA.” News release.

Singh, V. (May 1999). "Clean Government: Options for Government to Buy Renewable Energy.” REPP Issue Brief No. 12. Washington, DC: Renewable Energy Policy Project.

Swezey, B.; Bird, L. (August 2000). Green Power Marketing in the United States: A Status Report. NREL/TP-620-28738. Golden, CO: National Renewable Energy Laboratory.

Tanaka, W. (May 14, 2000). "Consumers Turn to Internet for Electric Bargains.” Philadelphia Inquirer.

Tomich, J. (May 7, 2000). “Dot.coms Wage Utility War.” Arkansas Online.

USPS. (April 21, 2000). "Spring Cleaning at the U.S. Postal Service.” News release. 
Vilas, F. (November 10, 2000). Personal communication. Partners for Environmental Quality.

Wentworth, S. (March 27, 2000). Personal communication. City of Oakland.

Wiser, R.; Bolinger, M.; Holt, E. (August 2000). "Customer Choice and Green Power Marketing: A Critical Review and Analysis of Experience to Date." Proceedings of the 2000 ACEEE Summer Study. Washington, DC: American Council for an Energy-Efficient Economy.

Zanos, Y. (May 30, 2000). "Post Your Problems: Electric Supplier Choice Complicates Utility Decisions." Pittsburgh Post-Gazette. 


\section{REPORT DOCUMENTATION PAGE}

Form Approved OMB NO. 0704-0188

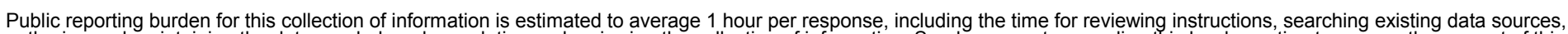

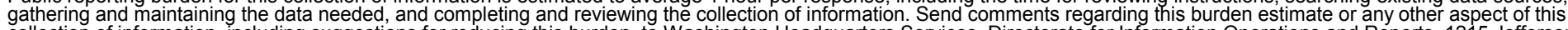

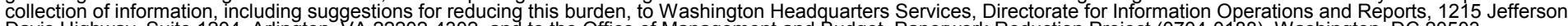
Davis Highway, Suite 1204, Arlington, VA 22202-4302, and to the Office of Management and Budget, Paperwork Reduction Project (0704-0188), Washington, DC 20503.
1. AGENCY USE ONLY (Leave blank)
2. REPORT DATE
February 2001
3. REPORT TYPE AND DATES COVERED
Technical Report

4. TITLE AND SUBTITLE

Customer Aggregation: An Opportunity for Green Power?

5. FUNDING NUMBERS

6. AUTHOR(S)

Edward Holt and Lori Bird

7. PERFORMING ORGANIZATION NAME(S) AND ADDRESS(ES)

8. PERFORMING ORGANIZATION REPORT NUMBER

National Renewable Energy Laboratory

1617 Cole Blvd.

NREL/TP-620-29408

Golden, CO 80401-3393

9. SPONSORING/MONITORING AGENCY NAME(S) AND ADDRESS(ES)

10. SPONSORING/MONITORING AGENCY REPORT NUMBER

11. SUPPLEMENTARY NOTES

12a. DISTRIBUTION/AVAILABILITY STATEMENT

National Technical Information Service

12b. DISTRIBUTION CODE

U.S. Department of Commerce

5285 Port Royal Road

Springfield, VA 22161

13. ABSTRACT (Maximum 200 words)

This report explores the experience of aggregation groups to determine whether customer aggregation offers an opportunity to bring green power choices to more customers. The objectives of this report are to (1) identify the different types of aggregation that are occurring today; (2) learn whether aggregation offers an opportunity to advance sales of green power; and (3) share these concepts and approaches with potential aggregators and green power advocates.

14. SUBJECT TERMS

15. NUMBER OF PAGES

Green power; green power marketing; customer aggregation; aggregated purchasing; bulk purchasing; green electricity; buying pools; customer choice

17. SECURITY CLASSIFICATION OF REPORT Unclassified
18. SECURITY CLASSIFICATION OF THIS PAGE Unclassified
19. SECURITY CLASSIFICATION OF ABSTRACT Unclassified
16. PRICE CODE

20. LIMITATION OF ABSTRACT

UL 